Article

\title{
Transition Metal Sulfides- and Noble Metal-Based Catalysts for N-Hexadecane Hydroisomerization: A Study of Poisons Tolerance
}

\author{
Aleksey Pimerzin 1,2,*(D), Aleksander Savinov ${ }^{2}$, Anna Vutolkina 1,3, Anna Makova ${ }^{1}$, \\ Aleksandr Glotov ${ }^{1}$ (D), Vladimir Vinokurov ${ }^{1}$ and Andrey Pimerzin ${ }^{2}$ \\ 1 Gubkin Russian State University of Oil and Gas, Department of Chemical Technology and Ecology, \\ Division of Physical and Colloid Chemistry, 65 Leninsky Prosp, 119991 Moscow, Russia; \\ annavutolkina@mail.ru (A.V.); ankamackova@yandex.ru (A.M.); glotov.a@gubkin.ru (A.G.); \\ vinok_ac@mail.ru (V.V.) \\ 2 Samara State Technical University, Department of Chemical Technology, \\ Division of Chemical Technology of Oil and Gas Refinery, 244 Molodogvardeyskaya Street, \\ 443100 Samara, Russia; savinooov13@gmail.com (A.S.); pimerzin.aa@samgtu.ru (A.P.) \\ 3 Lomonosov Moscow State University, Department of Chemistry, \\ Division of Petroleum Chemistry and Organic Catalysis, 3, 1 Leninskie Gory, 119991 Moscow, Russia \\ * Correspondence: al.pimerzin@gmail.com; Tel.: +7-846-242-3580
}

Received: 24 April 2020; Accepted: 21 May 2020; Published: 26 May 2020

\begin{abstract}
Bifunctional catalysts on the base of transition metal sulfides (CoMoS and NiWS) and platinum as noble metal were synthesized via wetness impregnation of freshly synthesized $\mathrm{Al}_{2} \mathrm{O}_{3}$-SAPO-11 composites, supported with favorable acidic properties. The physical-chemical properties of the prepared materials were studied by X-ray diffraction (XRD), scanning electron microscopy (SEM), low-temperature $\mathrm{N}_{2}$ adsorption and high resolution transmission electron microscopy (HR TEM) methods. Catalytic properties were studied in n-hexadecane isomerization using a fixed-bed flow reactor. The catalytic poisons tolerance of transition metal sulfides (TMS)- and Pt-catalysts has been studied for sulfur and nitrogen, with the amount of 10-100 ppm addition to feedstock. TMS-catalysts show good stability during sulfur-containing feedstock processing, whereas Pt-catalyst loses much of its isomerization activity. Nitrogen-containing compounds in the feedstock has a significant impact on the catalytic activity of both TMS and Pt-based catalysts.
\end{abstract}

Keywords: hydroisomerization; n-alkanes; bifunctional catalysts; stability; CoMoS; NiWS; Pt; catalytic poisons

\section{Introduction}

Nowadays, transformation of n-alkanes to corresponding branched forms by hydroconversion, i.e., hydrocracking or hydroisomerization, is becoming more important for the petroleum refinery and petrochemical industry [1-5]. This process plays a significant role in the production of high-quality gasoline and diesel fuels, as well as motor oils. Diesel and gasoline oil fraction treatment transforms the high freezing long-chain n-paraffins, and contributes to the improvement of the octane number of gasoline and the low-temperature performance of diesel or lubricating oils [6-10]. One of hydroisomerization's advantages is the high yield of liquid products. These light fractions do not have any sulfur, but contain branched alkanes with high octane numbers, which causes isomerization products to be the most valuable component of gasoline. Hydroisomerization of linear long-chain hydrocarbons is becoming more important considering ecological restrictions [11,12]. 
Hydroisomerization catalysts are bifunctional systems, containing metal particles acting as hydrogenation/dehydrogenation sites and acidic mesoporous support, providing acid sites for isomerization $[13,14]$. The hydrogenation/dehydrogenation activity of hydroisomerization catalysts is provided by the metallic sites, typically $\mathrm{Pt}$, supported on acidic mesoporous carriers [13,15-17]. Different kinds of zeolites, natural clays and aluminosilicates are widely used as supports for bifunctional catalysts [18-24].

According to widely acknowledged hydroisomerization mechanisms, n-alkanes are dehydrogenated on metallic active sites to form alkene intermediates. The resulted olefins are protonated and isomerized mainly on Brønsted acid sites, followed by rapid hydrogenation over metal sites to the corresponding branched iso-alkanes (Figure 1) $[25,26]$. Besides, the length of the hydrocarbon chain is considered to be correlated with the reactivity thereof [27]. Thus, the acidity properties are inversely proportional to the chain length [1]. Therefore, the selectivity of the catalyst towards isomerization is affected by a proper balance between metallic and acidic sites.

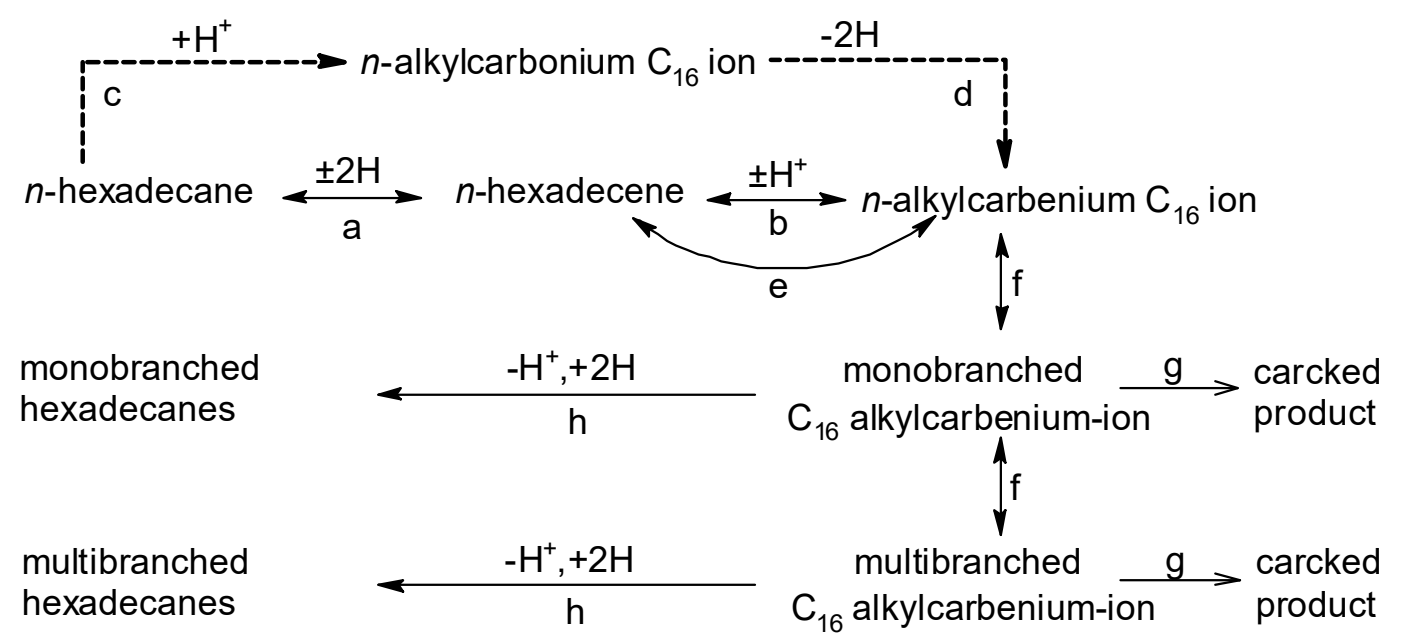

Figure 1. Scheme of n-hexadecane hydroisomerization. a-Hydrogenation-dehydrogenation on metallic sites; $\mathbf{b}$-Protonation-deprotonation on acid sites; $\mathbf{c}$-Addition of proton to form alkylcarbonium ion on acid; $\mathbf{d}$-Dehydrogenation to form alkylcarbenium ion; $\mathbf{e}$-Competitive adsorption-desorption of alkene and carbenium ion on acid sites; $\mathbf{f}$-Rearrangement of alkylcarbenium ion; $\mathbf{g}$-Cracking of alkylcarbenium ion; $\mathbf{h}-$ Hydrogenation to form alkane on metallic sites.

The structural properties of the support also affect the shape-selectivity of molecular sieves. In general, the smaller the zeolite pore size, the lower the methyl branching [28,29]. While for microporous molecular sieves methyl branching takes place, for wide pore openings and large cavities, ethyl and propyl branched isomers are obtained [7,30]. Multibranched isomers formed during n-paraffins isomerization are more susceptible to hydrocracking, which leads thereby to lower isomerization selectivity [31]. The support structure and textural properties are also crucial for long-chain isomerization from the point of view of diffusion limitations, due to the transformation of linear alkanes occurring in the micropores: the rapid diffusion of molecules to the bulk phase should be provided before the undesired cracking reactions occur.

The hydrogenation/dehydrogenation activity of hydroisomerization catalysts is provided by metallic sites, typically Pt, supported on acidic mesoporous carriers [13,15]. Different kinds of zeolites, natural clays and aluminosilicates are widely used as supports for bifunctional catalysts [18-24]. The most significant characteristic for these catalysts from an industrial viewpoint is stability to poisons [32,33]. Noble metal-based catalysts stand out as more active for hydroisomerization when the content of the active metals is higher than $0.5 \mathrm{wt} \%$, which makes them very expensive [34-37]. Moreover, catalyst poisoning by nitrogen- and sulfur-containing compounds leads to dramatic decreases in activity [38-41]. Metal active sites poisoning by sulfur involves hydrogen sulfide adsorption followed 
by its dissociation, leading to rearrangement of the metal surface, wherein the polysulfide layer forms, and catalyst deactivation is reversible. When the $\mathrm{S} / \mathrm{Pt}$ ratio is higher than 0.4 , the poisoning becomes irreversible. This may also be caused by strong Pt-S covalent bonding [42]. The deactivation of the noble metal-based catalysts by nitrogen-containing compounds takes place due to their strong adsorption on the acid sites of the support. As a result, the content of available active sites decreases, which has a negative influence on catalytic activity [43]. Therefore, the industrial application of noble metal-based catalysts for hydroisomerization is limited, and research focuses shift towards novel low-cost bifunctional catalysts with sufficient activity and stability. As such, the development of transition metal-containing catalysts for hydroisomerization of linear alkanes is of both scientific and industrial interest [44-47].

The most promising sulfur tolerance catalysts are transition metal sulfides. The transition metal sulfides providing high catalytic activity are widely used for hydrotreatment processes [44,48-51]. CoMo bimetallic catalysts have been investigated for ethylbenzene hydrogenation [34]. Appropriate acidity of the support favors the hydrogenation/isomerization activity of the catalysts, which allows the performance of ultra-deep sulfur removal from oil fractions [52-54].

A number of microporous zeolites, such as ZSM-22, ZSM-23 and ZSM-48, were used as functional supports for hydroisomerization catalysts. Among one-dimensional porous materials, structured SAPO-11 exhibits appropriate acidity and shape-selectivity, making it one of the more promising supports for hydroisomerization catalysts. This silicoaluminophosphate, consisting of $\mathrm{Al}_{2} \mathrm{O}_{3}, \mathrm{SiO}_{2}$ and $\mathrm{P}_{2} \mathrm{O}_{5}$ as the main components, has a one-dimensional, 10-membered ring channel system, with an elliptical pore opening of $0.44 \times 0.64 \mathrm{~nm}$ [55]. Thanks to moderate acidity and shape-selectivity, the medium-pore SAPO-11 acts as a functional support for isomerization catalysts, favoring selective isomerization of long-chain alkanes (for monomethyl isomers) [56]. Thus, SAPO-11-supported Pt-catalysts were found to exhibit high selectivity to skeletal isomers in n-dodecane hydroisomerization at $300{ }^{\circ} \mathrm{C}$ and hydrogen pressure of 1 bar (weight hourly space velocity (WHSV) $=2 \mathrm{hr}^{-1}$ ) [57]. Similar results were obtained in [58], when $1 \mathrm{wt} \%$ of Pt was loaded on SAPO-11 and tested at $307^{\circ} \mathrm{C}$ under higher hydrogen pressure (20 bar). Ni-Mo-SAPO-11-catalysts have demonstrated a high selectivity to $\mathrm{C}_{18}$ hydrocarbons $(57 \%)$ at $350{ }^{\circ} \mathrm{C}$ under 30 bar [45]. More recently, the SAPO-11-supported CoMo-catalyst has been applied in n-hexadecane hydroisomerization, and exhibited comparable activity with noble metals-based catalysts [59].

Herein, we examined the stability of transition metal-containing catalysts in terms of the isomerization function of $n$-alkanes to poisoning by nitrogen and sulfur compounds. This investigation also includes calculations of kinetic parameters, evaluating the n-paraffin isomerization selectivity depending on sulfur and nitrogen influence.

\section{Results}

The key factor, from the industrial viewpoint, in catalyst application, is mechanical stability, provided by supports. In general, hydroisomerization catalysts are formed into pellets by the extrusion of functional acidic components mixed with boehmite. The latter provides $\gamma-\mathrm{Al}_{2} \mathrm{O}_{3}$ formation after calcination at $550-600{ }^{\circ} \mathrm{C}[15,59]$. Thus, we here report the examination of pelletized $\mathrm{Al}_{2} \mathrm{O}_{3}$-SAPO-11-supported $\mathrm{Pt}$ and transition metal sulfide catalysts in the hydroisomerization of $\mathrm{n}$-hexadecane in the presence of poisons. The SAPO-11 component in these catalysts has appropriate acidity and provides selectivity in hydroisomerization reactions.

\subsection{Physical-Chemical Properties of the Solids}

Figure $\mathrm{S} 1$ shows the diffraction pattern of synthesized $\mathrm{Al}_{2} \mathrm{O}_{3}$-SAPO- 11 support. Observed signals on the recorded XRD pattern for $\mathrm{Al}_{2} \mathrm{O}_{3}-\mathrm{SAPO}-11$ material are consistent with standard SAPO-11 (PDF 047-0614) and $\mathrm{Al}_{2} \mathrm{O}_{3}$ (PDF 075-0921).

Figure $\mathrm{S} 2$ shows the SEM image of the prepared $\mathrm{Al}_{2} \mathrm{O}_{3}-\mathrm{SAPO}-11$ support. SEM images of the composite support surface looks like a mixture of alumina, with a smooth surface and well-dispersed 
crystals of silicoaluminophosphate, as can be seen from energy dispersive $\mathrm{X}$-rays analysis (EDX) mapping (Figure 2). SAPO-11 particles (1-5 $\mu \mathrm{m}$ ) are uniformly distributed over the $\mathrm{Al}_{2} \mathrm{O}_{3}$ surface. The structure of the SAPO-11 crystals does not look damaged by acid.
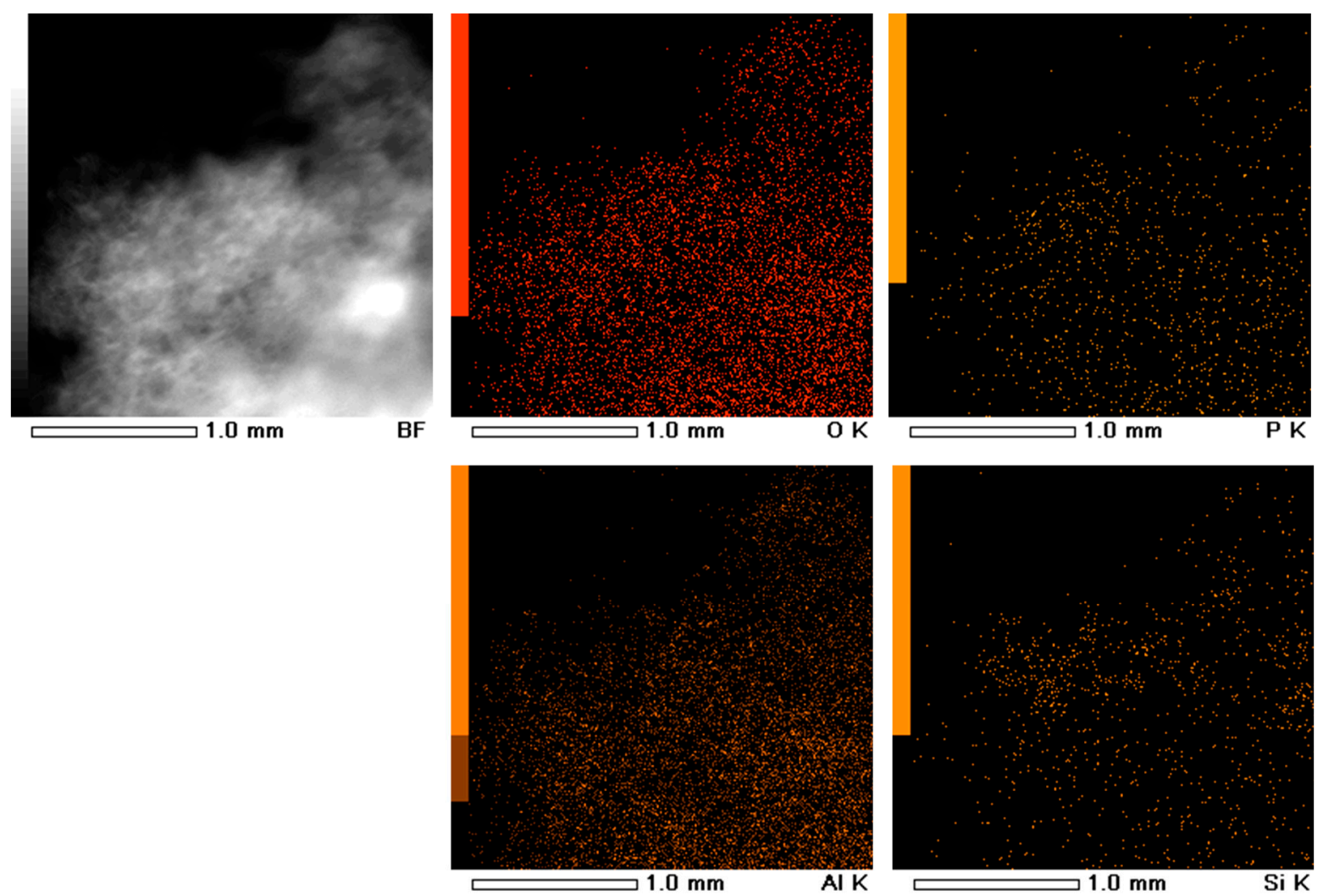

Figure 2. EDX image mapping of the elements on composite $\mathrm{Al}_{2} \mathrm{O}_{3}-\mathrm{SAPO}-11$ support.

The textural properties of the prepared $\mathrm{Al}_{2} \mathrm{O}_{3}-\mathrm{SAPO}-11$ composite support and bifunctional catalysts were measured by low-temperature $\mathrm{N}_{2}$ adsorption. The nitrogen adsorption-desorption isotherms and pore size distributions of the support and synthesized catalysts are shown in Figure 3. Synthesized materials exhibited a typical type I-type IV combination of isotherms, indicating a micro-mesoporous starting material. The total nitrogen adsorbed is slightly higher for the support, according to its higher pore volume. In particular, the steep uptake at lower relative pressure $\left(\mathrm{P} / \mathrm{P}_{0}<0.05\right)$ indicates the $\mathrm{N}_{2}$ filling in the micropores of the SAPO-11 phase. Meanwhile, all the prepared catalysts and composite supports show isotherms with an obvious H3 + H4 hysteresis loop, which is the result of the composite support's nature, combining the micropores of SAPO-11 and the slit-shaped pores of alumina.

The textural properties of the prepared $\mathrm{Al}_{2} \mathrm{O}_{3}-\mathrm{SAPO}-11$ composite supports and transition metal sulfide (TMS) catalysts, as well as the reference Pt-catalyst, are listed in Table 1. All the prepared materials offer bimodal characteristics of pore size distribution (Figure 3). Pores with an average diameter about $3.8 \mathrm{~nm}$ ( $t$-plot) correspond to SAPO-11, and the other ones, with $8.0 \mathrm{~nm}$ diameter, are related to alumina. Active metals loading has no significant effect on the textural properties of the supported catalysts. Specific surface area decreases from 268 to about $200 \mathrm{~m}^{2} / \mathrm{g}$ in the case of sulfide catalysts synthesis, and keeps almost constant for Pt-catalyst. The average pore volume and micropore properties evaluated, by t-plot and density functional theory (DFT) methods, do not change after catalysts' impregnation (Table 1). 




(a)



(b)

Figure 3. $\mathrm{N}_{2}$ adsorption isotherms (a) and pore size distribution curves (b) of composite support (curves a) and prepared catalysts (curves b).

Table 1. Textural properties of the prepared solids.

\begin{tabular}{ccccccc}
\hline \multirow{2}{*}{ Catalyst (Support) } & \multicolumn{3}{c}{ Brunauer-Emmett-Teller (BET) } & \multicolumn{3}{c}{$t$-Plot \& DFT } \\
\cline { 2 - 7 } & $\mathbf{S}_{\text {BET }}$ & $\mathbf{D}_{\mathbf{p}}$ avr. & $\mathbf{V}_{\text {pore }}$ & $\mathbf{S}_{\text {micro }}$ & $\mathbf{D}_{\text {micro }}$ & $\mathbf{V}_{\text {micro }}$ \\
\cline { 2 - 7 } & $\mathbf{( \mathbf { m } ^ { 2 } / \mathbf { g } )}$ & $\mathbf{( n m )}$ & $\mathbf{( \mathbf { c m } ^ { 3 } / \mathbf { g } )}$ & $\mathbf{( \mathbf { m } ^ { 2 } / \mathbf { g } )}$ & $\mathbf{( \mathbf { n m } )}$ & $\mathbf{( \mathbf { c m } ^ { 3 } / \mathbf { g } )}$ \\
\hline $\mathrm{Al}_{2} \mathrm{O}_{3}-\mathrm{SAPO}-11$ (support) & 268 & $<4.0 \& 8.1 *$ & 0.50 & 69 & 3.8 & 0.06 \\
\hline $\mathrm{CoMoS} / \mathrm{Al}_{2} \mathrm{O}_{3}-\mathrm{SAPO}-11$ & 204 & $<4.0 \& 8.0 *$ & 0.49 & 66 & 3.7 & 0.05 \\
\hline $\mathrm{NiWS} / \mathrm{Al}_{2} \mathrm{O}_{3}-\mathrm{SAPO}-11$ & 198 & $<4.0 \& 7.9 *$ & 0.47 & 64 & 3.8 & 0.05 \\
\hline $\mathrm{Pt} / \mathrm{Al}_{2} \mathrm{O}_{3}-\mathrm{SAPO}-11$ & 259 & $<4.0 \& 8.1 *$ & 0.51 & 59 & 3.7 & 0.04 \\
\hline
\end{tabular}

Figure 4 shows representative HR TEM micrographs of the prepared catalysts. The active phase of CoMoS- and NiWS-catalysts is preceded by the typically well-dispersed sulfide phase-Hexagonal crystallites of $\mathrm{Mo}(\mathrm{W}) \mathrm{S}_{2}$ decorated with $\mathrm{Co}(\mathrm{Ni})$ atoms on the edges, as presented in Topsøe's works $[44,60,61]$. On the HR TEM pictures, the sulfide phase looks like single or stacked dark stripes. The average length of CoMoS sulfide's active phase is $3.6 \mathrm{~nm}$, and a stacking number of 2.1 resulted in dispersion equal to 0.33 (Table 2). NiWS's active phase is characterized by average length of $4.6 \mathrm{~nm}$ and stacking number 1.9 , resulting in 0.27 dispersion. The active phase of the reference Pt-catalyst is presented by nanosized metal clusters dispersed on the catalyst surface. The average particle size of Pt clusters on the surface of $\mathrm{Pt} / \mathrm{Al}_{2} \mathrm{O}_{3}-\mathrm{SAPO}-11$-catalyst is $1.5 \mathrm{~nm}$.

The acidic properties of CoMoS and NiWS-based bifunctional catalysts have been studied with the $\mathrm{NH}_{3}$-TPD method, and the amounts of desorbed ammonia are presented in Table 2. The measured acidic properties of sulfide catalysts provide very close values of desorbed $\mathrm{NH}_{3}$ for each type of acid site, and are in accordance with previously obtained results [62]. Sulfide active phase formation leads to an increase in the amount of high-temperature active sites, in comparison with $\mathrm{Al}_{2} \mathrm{O}_{3}$-SAPO- 11 support, from 0.22 up to $0.62 \mathrm{mmol} / \mathrm{g}$. The NiWS-catalyst exhibits slightly higher total acidity evaluated by $\mathrm{NH}_{3}$-TPD, about $10 \%$ relative to CoMoS-catalyst. Catalytic properties of the $\mathrm{Pt} / \mathrm{Al}_{2} \mathrm{O}_{3}$-SAPO-11-catalyst are almost equal to the initial composite support, most likely due to low concentration of platinum. 


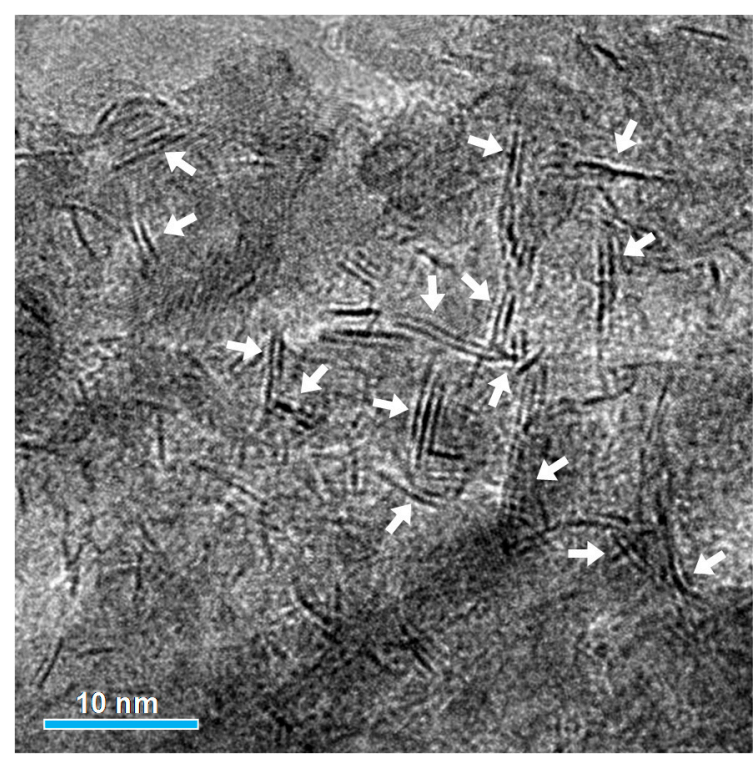

(a)

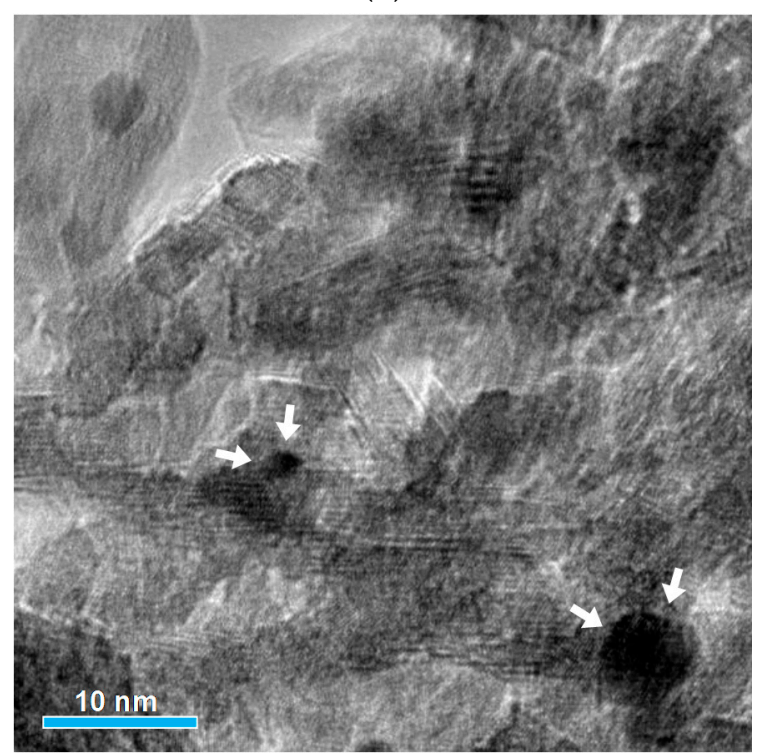

(c)



(b)

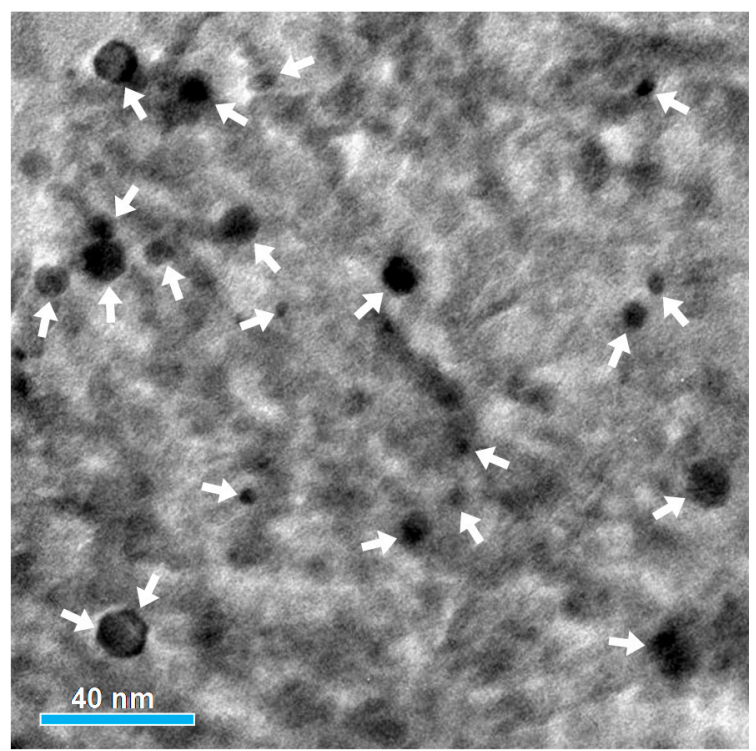

(d)

Figure 4. HR TEM micrographs of the synthesized bifunctional catalysts: (a) $\mathrm{CoMoS} / \mathrm{Al}_{2} \mathrm{O}_{3}-\mathrm{SAPO}-11$, (b) $\mathrm{NiWS} / \mathrm{Al}_{2} \mathrm{O}_{3}-\mathrm{SAPO}-11$, (c,d) $\mathrm{Pt} / \mathrm{Al}_{2} \mathrm{O}_{3}-\mathrm{SAPO}-11$. 
Table 2. Metals content and active phase properties of the prepared catalysts.

\begin{tabular}{|c|c|c|c|}
\hline \multirow[b]{2}{*}{ Parameter } & \multicolumn{3}{|c|}{ Catalyst } \\
\hline & $\begin{array}{c}\text { CoMoS/ } \\
\mathrm{Al}_{2} \mathrm{O}_{3}-\mathrm{SAPO}-11 \\
\end{array}$ & $\begin{array}{c}\mathrm{NiWS} / \\
\mathrm{Al}_{2} \mathrm{O}_{3} \text {-SAPO-11 }\end{array}$ & $\begin{array}{c}\mathrm{Pt} / \\
\mathrm{Al}_{2} \mathrm{O}_{3}-\mathrm{SAPO}-11 \\
\end{array}$ \\
\hline \multicolumn{4}{|l|}{ Active metals loading (wt \%) } \\
\hline - $\quad \mathrm{Mo}(\mathrm{W})$ or $\mathrm{Pt}$ (for ref. catalyst) & 10.6 & 18.5 & 1.0 \\
\hline - $\quad \mathrm{Co}(\mathrm{Ni})$ & 3.1 & 3.0 & - \\
\hline \multicolumn{4}{|l|}{ Active phase morphology } \\
\hline $\begin{array}{l}\text { Average length, } \bar{L}(\mathrm{~nm}) \\
\text { (diameter for ref. catalyst) }\end{array}$ & 3.6 & 4.6 & 1.5 \\
\hline - $\quad$ Average stacking number, $\bar{N}$ & 2.1 & 1.9 & - \\
\hline - $\quad$ Dispersion of active phase, $D$ & 0.33 & 0.27 & 0.91 \\
\hline \multicolumn{4}{|l|}{ Acidity-TPD $\mathrm{NH}_{3}, \mathrm{mmol} / \mathrm{g}$ * } \\
\hline - Weak & 0.421 & 0.423 & 0.367 \\
\hline - $\quad$ Medium & 0.193 & 0.204 & 0.261 \\
\hline - $\quad$ Strong & 0.507 & 0.616 & 0.236 \\
\hline - $\quad$ Total & 1.121 & 1.243 & 0.865 \\
\hline
\end{tabular}

\subsection{Catalytic Properties Examination}

It is well-known that Pt-containing bifunctional catalysts are much more active than other ones, nevertheless, several previous studies have shown the possibility of using the transition metal-based catalysts application for n-alkanes hydroisomerization. Figure 5 shows the comparison between the reaction rate constant of n-hexadecane isomerization at various temperatures with CoMoS-, NiWS- and Pt-catalysts, supported with $\mathrm{Al}_{2} \mathrm{O}_{3}-\mathrm{SAPO}-11$ support. The obtained results correlate with published data $[59,62]$. The difference in activity between Pt- and TMS-based catalysts gradually decreases as the temperature increases from 300 to $340{ }^{\circ} \mathrm{C}$. The Pt-catalyst demonstrates a reaction rate constant 10 times higher at $300{ }^{\circ} \mathrm{C}$ and 4.5 times higher at $340{ }^{\circ} \mathrm{C}$, compared to the NiWS-catalyst (Figure 5). The increased temperature of the process is likely favorable for TMS-catalysts application. Methyl- and ethylpentadecanes were the main products of the isomerization reaction. Coke formation, as well as cracking products, were not observed under the studied conditions for any experiments.

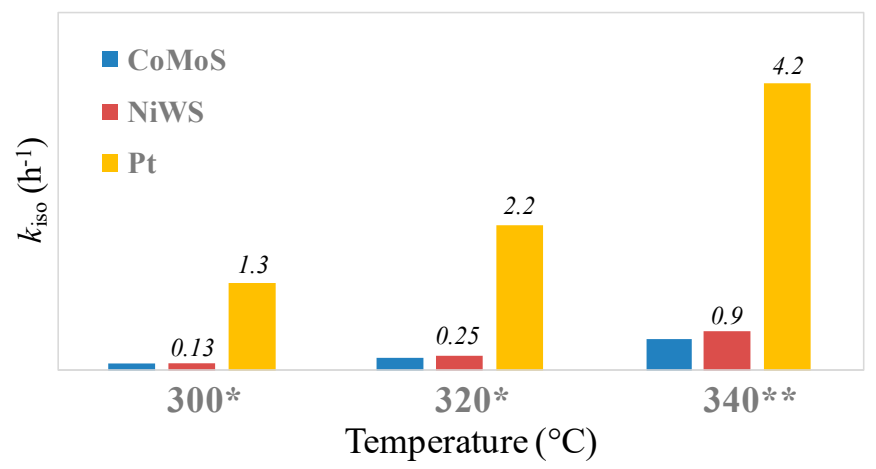

Figure 5. Reaction rate constants of n-hexadecane isomerization at $300-340{ }^{\circ} \mathrm{C}$, versus $\mathrm{Al}_{2} \mathrm{O}_{3}-\mathrm{SAPO}-11$ supported CoMoS-, NiWS- and Pt-catalysts. *-Results adopted from [59,62], **-Results obtained in this work. 
Catalytic stability tests for all catalysts have been performed with sulfur- and nitrogen-containing feeds at constant reaction conditions. Table 3 summarizes the obtained results of catalytic activity measurements of TMS- and Pt-based catalysts. CoMoS- and NiWS-catalysts demonstrate perfect stability during the experiments with sulfur-containing feedstock. The conversion of n-hexadecane keeps constant, 53\% and 59\% for CoMoS- and NiWS-catalysts, respectively, while processing feeds with up to $100 \mathrm{ppm}$ of sulfur. Reaction rate constants are comparable for both sulfide catalysts in the experiments with sulfur-containing feedstocks, and equal to the initial values for pure $n-C_{16}$ processing. Consequently, the inhibiting effect of sulfur on TMS-catalysts is equal to zero. The Pt-based catalyst is exposed to sulfur poisoning more intensively. The addition of $10 \mathrm{ppm}$ sulfur into the feedstock reduces $\mathrm{n}-\mathrm{C}_{16}$ conversion from $79 \%$ to $52 \%$, which is valued at $53 \%$ activity inhibition, but the residual activity nevertheless is higher than for the NiWS- or CoMoS-catalysts. The sulfur concentration increasing up to $100 \mathrm{ppm}$ has a dramatic $(77 \%)$ inhibiting effect on the Pt-catalyst. The isomerization reaction rate constant is $0.35 \pm 0.006 \times 10^{-4}\left(\mathrm{~mol} \mathrm{~g}^{-1} \mathrm{~h}^{-1}\right)$, which is almost three times lower than NiWS-catalyst's one. For all experiments, hydroisomerization selectivity was almost $100 \%$, and no cracking products were observed.

Table 3. Catalytic performance of TMS-based and reference Pt-catalyst in n-hexadecane hydroisomerization at $340{ }^{\circ} \mathrm{C}, 1.5 \mathrm{MPa}, 150 \mathrm{~nL} / \mathrm{L} \mathrm{H}_{2}$ to feedstock ratio.

\begin{tabular}{|c|c|c|c|c|c|c|}
\hline \multirow{3}{*}{$\begin{array}{c}\text { Catalyst \& Reaction } \\
\text { Parameter }\end{array}$} & \multicolumn{6}{|c|}{ Reaction Conditions $\left(\mathrm{T}=340^{\circ} \mathrm{C}, \mathrm{P}=15 \mathrm{bar}, \mathrm{H}_{2} /\right.$ Feedstock $\left.=150 \mathrm{~nL} / \mathrm{L}\right)$} \\
\hline & \multirow{2}{*}{ WHSV $\left(h^{-1}\right)$} & \multicolumn{5}{|c|}{ Feedstock: N-Hexadecane $2.9 \mathrm{wt} \%$ + Catalytic Poison } \\
\hline & & No Poison & 10 ppmS & 100 ppmS & $10 \mathrm{ppmN}$ & $50 \mathrm{ppmN}$ \\
\hline \multicolumn{7}{|l|}{$\mathrm{CoMoS} / \mathrm{Al}_{2} \mathrm{O}_{3}$-SAPO-11 } \\
\hline - $\quad \mathrm{n}-\mathrm{C}_{16}$ conversion $(\%)$ & 1.0 & 52.8 & 53.1 & 52.0 & 29.8 & 12.4 \\
\hline - $\quad k_{\text {iso }} \times 10^{4}\left(\mathrm{~mol} \mathrm{~g}^{-1} \mathrm{~h}^{-1}\right)$ & & $0.76 \pm 0.02$ & $0.77 \pm 0.02$ & $0.74 \pm 0.01$ & $0.36 \pm 0.01$ & $0.13 \pm 0.003$ \\
\hline - Inhib. effect & & - & - & $2 \%$ & $52 \%$ & $83 \%$ \\
\hline \multicolumn{7}{|l|}{$\mathrm{NiWS} / \mathrm{Al}_{2} \mathrm{O}_{3}-\mathrm{SAPO}-11$} \\
\hline - $\quad n-C_{16}$ conversion $(\%)$ & 1.0 & 59.0 & 59.5 & 58.8 & 38.8 & 18.8 \\
\hline - $\quad k_{\text {iso }} \times 10^{4}\left(\mathrm{~mol} \mathrm{~g}^{-1} \mathrm{~h}^{-1}\right)$ & & $0.90 \pm 0.01$ & $0.92 \pm 0.02$ & $0.90 \pm 0.02$ & $0.50 \pm 0.01$ & $0.21 \pm 0.005$ \\
\hline - Inhib. effect & & - & - & $1 \%$ & $45 \%$ & $76 \%$ \\
\hline \multicolumn{7}{|l|}{$\mathrm{Pt} / \mathrm{Al}_{2} \mathrm{O}_{3}-\mathrm{SAPO}-11$} \\
\hline - $\quad \mathrm{n}-\mathrm{C}_{16}$ conversion $(\%)$ & 3.0 & 78.6 & 51.8 & 8.5 & 9.1 & 2.9 \\
\hline - $\quad k_{\text {iso }} \times 10^{4}\left(\mathrm{~mol} \mathrm{~g}^{-1} \mathrm{~h}^{-1}\right)$ & & $4.75 \pm 0.22$ & $2.2 \pm 0.044$ & $0.35 \pm 0.006$ & $0.29 \pm 0.01$ & $0.09 \pm 0.004$ \\
\hline - Inhib. effect & & - & $53 \%$ & $77 \%$ & $94 \%$ & $98 \%$ \\
\hline
\end{tabular}

Figure 6 is used to show, in a graphic outline, the comparison of residual catalytic activity, i.e., the measured activity after the n-hexadecane conversion stopped decreasing, of bifunctional catalysts during sulfur- and nitrogen-containing feedstock processing. Similar reaction conditions can be used in this case due to the higher inhibition effect of catalytic poisons on Pt-containing catalyst. A reaction rate constant more than two times lower was measured for Pt-catalyst in the experiment with $100 \mathrm{ppm}$ sulfur, resulting in residual $n-\mathrm{C}_{16}$ conversion becoming equal to $37 \%$, versus $59 \%$ for the NiWS-catalyst, meanwhile, the $10 \mathrm{ppm}$ of sulfur in the feedstock allows the Pt-catalyst to provide higher catalytic activity in $\mathrm{n}-\mathrm{C}_{16}$ isomerization (Figure 6a).

The calculated inhibition effect of $10 \mathrm{ppm}$ nitrogen-containing feed on CoMoS- and NiWS-catalysts is about $45-52 \%$, meaning that the reaction rate constant is only half of the initial one and the conversion of n-hexadecane decreases to $30 \%$ and $39 \%$ for CoMoS and NiWS samples, respectively (Table 3). The Pt-catalyst already demonstrates extremely low $\mathrm{n}-\mathrm{C}_{16}$ conversion at studied reaction conditions when 10 ppm of nitrogen is added. The inhibiting effect is $94 \%$ in this case. The increasing of the nitrogen content to $50 \mathrm{ppm}$ in the feedstock dramatically drops n-hexadecane conversion measured 
for all the prepared catalysts. CoMoS- and NiWS-catalysts lose $83 \%$ and $76 \%$ of their initial activity, respectively. The observed n-hexadecane conversion over the Pt-catalyst is almost equal to zero; only about $3 \%$ of $\mathrm{C}_{16}$ isomers are detected in the product. Such low values of n-hexadecane conversion measured for Pt-catalyst in the nitrogen-containing feedstock processing is connected with the high WHSV $3.0 \mathrm{~h}^{-1}$, which was chosen for the Pt-catalyst due to the extremely high catalytic activity in pure $\mathrm{n}-\mathrm{C}_{16}$ hydroisomerization. However, by paying attention to the isomerization reaction rate constants calculated for all the catalysts (Table 3), it becomes possible to conclude that the catalytic behavior of the studied TMS- and Pt-based bifunctional catalysts is quite similar in nitrogen-containing feedstock processing.

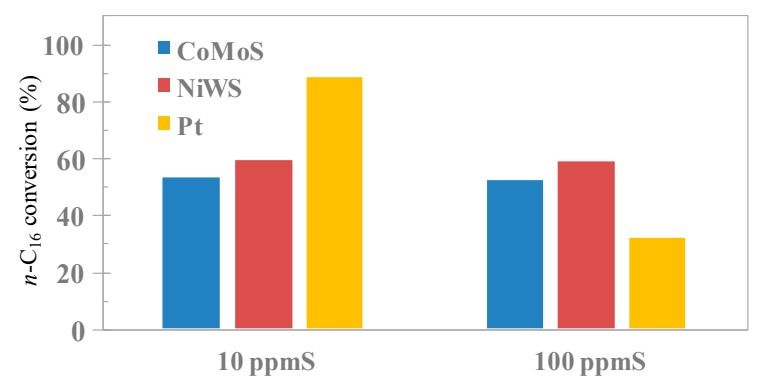

(a)

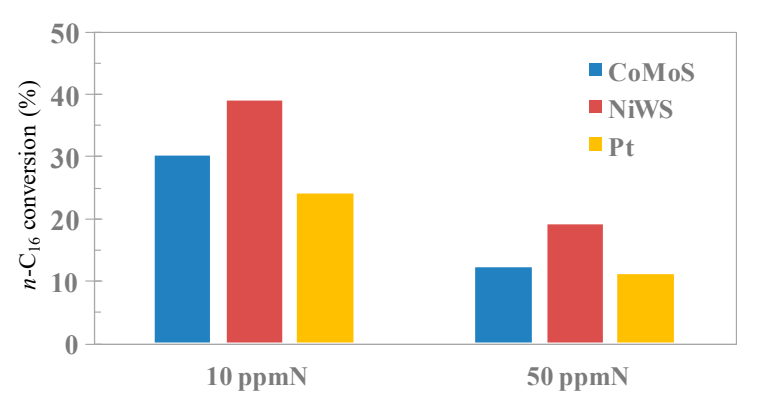

(b)

Figure 6. Conversion of $\mathrm{n}-\mathrm{C}_{16}$ (with sulfur (a) and nitrogen (b) poisoning) over TMS- and Pt-catalysts at similar conditions: $\left(\mathrm{T}=340^{\circ} \mathrm{C}, \mathrm{P}=15 \mathrm{bar}, \mathrm{WHSV}=1.0 \mathrm{~h}^{-1}, \mathrm{H}_{2} /\right.$ feedstock $\left.=150 \mathrm{~nL} / \mathrm{L}\right)$.

The comparison of the $\mathrm{n}-\mathrm{C}_{16}$ conversion with the prepared catalysts under the similar reaction conditions (Figure $6 \mathrm{~b}$ ) demonstrates quite clearly that the isomerization activity of synthesized TMS and- Pt-based bifunctional catalysts was inhibited by nitrogen through the similar mechanism, which differs from the one for Pt-catalysts poisoning by sulfur. The residual catalytic activity is the result of a strong limitation of the isomerization reaction in both TMS- and Pt-based catalysts caused by nitrogen in the feedstock. The logical explanation of such catalytic behavior is that nitrogen mostly poisons acid sites of bifunctional catalysts, leading thereby to decreases of acidity and isomerization activity, while the hydrogen sulphide changes the Pt into sulfide form, decreasing thereby its hydrogenation-dehydrogenation activity [7,33]. Since the TMS-based catalysts have already sulfided the active CoMoS or NiWS phase, sulfur in the feedstock has no inhibiting effect. The acid sites deactivating in the bifunctional catalysts is equally undesirable for both TMS- and Pt-containing catalysts.

In addition to the established difference in the inhibition effect of sulfur and nitrogen on Pt-catalyst activity, the rate of catalyst poisoning by the corresponding feedstock's undesired component was studied (Figure 7). The period of catalytic activity stabilization, in hours, required for reaching the steady state of n-hexadecane conversion was different when sulfur and nitrogen components were introduced into the feedstock. It took about $38 \mathrm{~h}$ during sulfur-containing feedstock processing to get the stable conversion of n-hexadecane (region " $c$ " on Figure 7a). The inhibiting effect of nitrogen was exhibited not only in a significant degree, but also more rapidly. It takes about $20 \mathrm{~h}$ for all the studied catalysts to get almost-steady n- $\mathrm{C}_{16}$ conversion-Region " $\mathrm{c}$ ", specified in Figure $7 \mathrm{~b}$. It is important to point out that catalytic activity stabilization for both TMS- and Pt-based catalysts takes the same period. Almost the same time interval is required to get a steady state when 10 and $50 \mathrm{ppm}$ of nitrogen are introduced into the feedstock. 




(a)

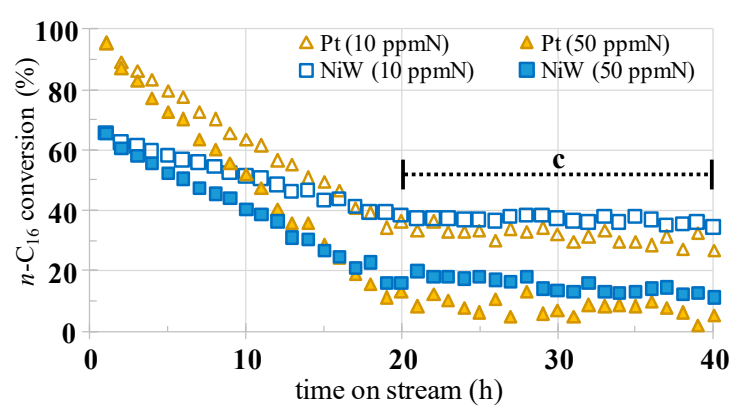

(b)

Figure 7. The dependence of the n-hexadecane conversion in time for sulfur-containing (a) and nitrogen-containing (b) feedstock processing.

The observed differences in poisoning kinetics are most likely connected with mechanisms focused on metal active sites in the case of sulfur poisoning of Pt-catalyst, and the acid sites of the silicoaluminophosphate component of the composite supports. In view of this, the NiWS-catalyst provides slightly higher tolerance to nitrogen in feedstock in comparison with CoMoS- and Pt-catalysts. NiWS sulfide's active phase exhibits moderate acidic properties, and is probably involved in the isomerization step of the $n-C_{16}$ reaction.

\section{Materials and Methods}

\subsection{Preparation of the Solids}

SAPO-11 was hydrothermally synthesized according to the reported procedure [63] from the pseudoboehmite (Sasol Company, Hamburg, Germany), orthophosphoric acid (Merck) and Ludox AS30 colloid silica (Aldrich), used as alumina, phosphorus and silicon sources, respectively. The final molar composition of the prepared gel was: $1.0 \mathrm{Al}_{2} \mathrm{O}_{3} ; 1.0 \mathrm{P}_{2} \mathrm{O}_{5} ; 0.3 \mathrm{SiO}_{2} ; 1.2 \mathrm{DPA} ; 45 \mathrm{H}_{2} \mathrm{O}$. The crystallization was performed in a Teflon-lined stainless steel autoclave at $200{ }^{\circ} \mathrm{C}$ for $24 \mathrm{~h}$. The product was water-washed, dried and calcined at $600^{\circ} \mathrm{C}$ for $6 \mathrm{~h}$ to obtain the SAPO- 11 material.

Composite $\mathrm{Al}_{2} \mathrm{O}_{3}$-SAPO- 11 support was prepared by mixing SAPO- 11 with $\mathrm{AlOOH}$ boehmite followed by incipient wetness impregnation with peptizer (concentrated nitric acid with modulus 0.04 ) and further molding by extrusion to form pellets with $2 \mathrm{~mm}$ diameter [15,59]. Pellets were dried at 80 and $110^{\circ} \mathrm{C}$ for $4 \mathrm{~h}$ at each temperature followed by calcination in air at $550{ }^{\circ} \mathrm{C}$ for $6 \mathrm{~h}$.

The bifunctional catalysts were prepared by incipient wetness impregnation technique. Composite $\mathrm{Al}_{2} \mathrm{O}_{3}$-SAPO- 11 support was crushed and sieved to particles between 0.25 and $0.50 \mathrm{~mm}$. CoMoS-catalyst was synthesized using 12-molybdophosphoric heteropolyacid (HPA) $\mathrm{H}_{3}\left[\mathrm{PMo}_{12} \mathrm{O}_{40}\right] \cdot \mathrm{nH}_{2} \mathrm{O}$ and cobalt (II) carbonate $\left(\mathrm{CoCO}_{3}\right)$. NiWS-catalyst was prepared from phosphotungstic acid $\mathrm{H}_{3}\left[\mathrm{PW}_{12} \mathrm{O}_{40}\right] \cdot \mathrm{nH}_{2} \mathrm{O}$ and nickel (II) carbonate $\left(\mathrm{NiCO}_{3}\right)$. Citric acid was used as a chelating agent. $\mathrm{An} \mathrm{H}_{2} \mathrm{PtCl}_{6}$ solution was used to prepare Pt-based catalysts. Aqueous impregnation solutions were prepared by dissolving all listed components in deionized water under continuous stirring at $50^{\circ} \mathrm{C}$. The amount of dissolving precursors and corresponding concentrations of active metals in solutions were calculated from the required metal loadings (Table 2). For example, for $\mathrm{CoMoS} / \mathrm{Al}_{2} \mathrm{O}_{3}-\mathrm{SAPO}-11$-catalyst preparation in amount of $50 \mathrm{~g}, 10.85 \mathrm{~g}$ of 12-molybdophosphoric HPA and $3.21 \mathrm{~g}$ of cobalt carbonate were dissolved in water with $6.02 \mathrm{~g}$ of citric acid. Then $40 \mathrm{~g}$ of freshly synthesized $\mathrm{Al}_{2} \mathrm{O}_{3}$-SAPO-11 carrier was impregnated with $36 \mathrm{~cm}^{3}$ of prepared solution. All impregnated materials were dried at $120^{\circ} \mathrm{C}$ for $4 \mathrm{~h}$. Pt-catalyst was further calcined at $450{ }^{\circ} \mathrm{C}(2 \mathrm{~h})$ and reduced just before catalytic testing in a hydrogen atmosphere at $400{ }^{\circ} \mathrm{C}$. TMS-catalysts were activated by sulfidating with a mixture of $15 \% \mathrm{H}_{2} \mathrm{~S}$ in $\mathrm{H}_{2}$ at $400{ }^{\circ} \mathrm{C}, 1.0 \mathrm{MPa}$ for $2 \mathrm{~h}$. 
The elemental analysis (Mo, $\mathrm{W}, \mathrm{Co}, \mathrm{Ni}$ and $\mathrm{Pt}$ ) of the prepared catalysts was performed by Shimadzu EDX800HS analyzer. SEM-EDX analysis was used to confirm the uniform distribution and check the possible agglomeration of active metals on the surface of the catalysts.

\subsection{Characterization of Supports and Catalysts}

X-ray powder diffraction measurements were performed on a Bruker D2 X-ray Diffraction system using $\mathrm{Cu} \mathrm{K} \alpha$ radiation $(\lambda=1.54056 \AA)$ with a scanning speed of $2.0^{\circ} / \mathrm{min}$. The powders were loaded on a glass disk by packing the samples into a cavity on the disk. The diffractograms were analyzed using standard JCPDS files.

The surface morphology of the supports was examined by scanning electronic microscopy (SEM) on a Carl Zeiss EVO 50 microscope.

The textural characteristics of the prepared supports and catalysts were measured by low-temperature $\mathrm{N}_{2}$ adsorption at $-196^{\circ} \mathrm{C}$ on a Quantachrome Autosorb-1 porosimeter after outgassing procedure under deep vacuum at $350{ }^{\circ} \mathrm{C}$ for $4 \mathrm{~h}$. Specific surface area (SSA) was calculated using the Brunauer-Emmett-Teller BET method. The total pore volume and pore size distribution were calculated from the desorption branch of the isotherm using the Barrett-Joiner-Halenda (BJH) model. Properties of micropores were evaluated using the $t$-plot method.

HR TEM images of the catalysts were obtained on a JEOL JEM-2100 microscope with electron tube voltage of $200 \mathrm{kV}$. To measure the key morphological characteristics at least 500 particles from 10-12 regions of the surface were handled for every sample. The average length of $\mathrm{Mo}(\mathrm{W}) \mathrm{S}$ slabs, as well as average number of slabs per stack, were calculated for TMS-catalysts according to the commonly accepted approach. The average diameter of active phase particles was evaluated in the case of Pt-catalyst. The dispersion (D) of active phase was calculated on the basis of geometric characteristics and evaluated as available atoms on the surface of metal clusters, with assumptions that active particles of metallic catalysts are spherical and $\mathrm{Mo}(\mathrm{W}) \mathrm{S}_{2}$ slabs are perfect hexagons [64-66].

\subsection{Catalytic Activity Examination}

The catalytic tests were performed using a fixed-bed flow reactor. A $2.5 \mathrm{~cm}^{3}$ volume of the catalyst was charged into the isothermal region of the reactor as particles of $0.25-0.50 \mathrm{~mm}$. All catalysts were activated before testing directly in the reactor. Pt-based catalyst was reduced in $0.5 \mathrm{MPa}$ hydrogen atmosphere at $400{ }^{\circ} \mathrm{C}$ for $2 \mathrm{~h}$, while TMS samples were sulfided at $400^{\circ} \mathrm{C}$ in an atmosphere of $\mathrm{H}_{2} \mathrm{~S} / \mathrm{H}_{2}$ for $2 \mathrm{~h}$. A mixture of $\mathrm{n}$-hexadecane $(2.9 \mathrm{wt} \%)$ in $\mathrm{n}$-heptane as a solvent with optional addition of dimethyl disulfide (DMDS) (as sulfur source) and quinolone (as nitrogen source) in 10-100 ppm concentration was introduced into the reactor as a model feedstock for evaluation of hydroisomerization performance and inhibiting effect. N-heptane was not reacted under the experimental conditions.

Catalytic activity was examined under the following conditions: temperature $340{ }^{\circ} \mathrm{C}, 1.5 \mathrm{MPa}$ $\mathrm{H}_{2}, 1-3 \mathrm{~h}^{-1}$ (weight hourly space velocity (WHSV), and a $150 \mathrm{~nL} / \mathrm{L}$ volume ratio of $\mathrm{H}_{2}$ to feedstock. The liquid product compositions of the samples collected every $1.0 \mathrm{~h}$ were determined using an Agilent 7890A Gas Chromatograph equipped with a Flame Ionization Detector and $30 \mathrm{~m}$ DB-5 Fused Silica capillary column $(30 \mathrm{~m} * 0.32 \mathrm{~mm} * 0.5 \mu \mathrm{m})$. Volume of injection was equal to $1.0 \mu \mathrm{m}$, the temperature of the injector and detector was $250{ }^{\circ} \mathrm{C}$. The program of temperature started from $60{ }^{\circ} \mathrm{C}$ and was raised to $180{ }^{\circ} \mathrm{C}$ with $5{ }^{\circ} \mathrm{C} / \mathrm{min}$ rate. Helium was used as carrier-gas. An example chromatogram is presented in Figure S3. The identification of the obtained reaction products was performed using gas chromatography/mass-spectrometry analysis and by matching retention times with available commercial standards. Methyl- and ethylpentadecanes were the main products of the reaction. The corresponding peaks on the chromatograms were located in the interval of 7.6-8.4 min retention time.

The hydroisomerization reaction was allowed to proceed for the period of time that provided the steady state of the process. In the case of sulfur and nitrogen addition into the feedstock this period varied from 20 to $38 \mathrm{~h}$. 
Conversion and isomerization selectivity were calculated using the following equations:

$$
x_{\text {iso }}=\frac{\text { consumed } n \text { - hexadecane }}{\text { initial } n-\text { hexadecane content }}=\frac{\text { iso }- \text { hexadecanes }}{\text { initial } n \text { - hexadecane content }}{ }^{\prime}
$$

The reaction rate constant of the hydroisomerization was determined using the following equation:

$$
k_{i s o}=-\frac{F}{m} \ln \left(1-x_{i s o}\right)
$$

where $k_{i s o}$ is the pseudo-first-order reaction constant for the n-hexadecane hydroisomerization ( $\mathrm{mol} \mathrm{g}^{-1}$ $\mathrm{h}^{-1}$ ); $x_{\text {iso }}$ is the conversion (\%) of $\mathrm{n}$-hexadecane into the $\mathrm{C}_{16}$ isomers; $F$ is the reactant (n-hexadecane) flow $\left(\mathrm{mol} \mathrm{h}^{-1}\right)$ and $m$ is the weight of the catalyst $(\mathrm{g})$.

The inhibiting effect was defined as the ratio of the reaction rate constant after reaching the steady state with poison-containing feedstock processing and the initial reaction rate constant.

$$
E_{\text {inh }}=\frac{k_{\text {iso }}}{k_{\text {iso }}^{0}},
$$

where $k_{i s o}^{0}$ is the initial reaction rate constant during pure n-hexadecane isomerization and $k_{i s o}$ is the reaction rate constant for poison-containing feedstock processing.

The residual catalytic activity declared in the manuscript refers to the values of catalytic activity measured after the n-hexadecane conversion stopped decreasing, in the cases of sulfuror nitrogen-containing feedstock.

\section{Conclusions}

Transition metal sulfide (CoMoS and NiWS) and platinum-containing bifunctional catalysts were prepared by a incipient wetness impregnation technique, using a freshly synthesized $\mathrm{Al}_{2} \mathrm{O}_{3}-\mathrm{SAPO}-11$ composite support with favorable acidic properties. The structure of the support was confirmed by powder XRD and SEM techniques. All the solids have comparable specific surface areas, from 200 to about $270 \mathrm{~m}^{2} / \mathrm{g}$, and the bimodal pore size distributions, with maximums at 3.8 and $8.0 \mathrm{~nm}$, come from SAPO-11's and alumina's nature, respectively. The introduction of active components has no significant effect on textural properties. The well-dispersed nanosized active phase of the prepared bifunctional catalysts was characterized by the HR TEM method to calculate morphological properties. The CoMoS active phase has slightly higher dispersion in comparison with the NiWS one.

CoMoS- and NiWS-catalysts demonstrate perfect stability during the experiments with sulfur-containing feedstock. The reaction rate constants are comparable for both sulfide catalysts during these experiments, and are equal to the initial values for pure $\mathrm{n}-\mathrm{C}_{16}$ processing; $0.8-0.9 \times 10^{4} \mathrm{~mol} \mathrm{~g}^{-1} \mathrm{~h}^{-1}$. Low sulfur concentration of $10 \mathrm{ppm}$ in feedstock inhibits Pt-catalysts by about 50\%. Regardless, Pt-catalyst provides more intense $\mathrm{n}-\mathrm{C}_{16}$ isomerization, and the reaction rate constant is two times higher in comparison with the NiWS-catalyst. The situation reverses when $100 \mathrm{ppm}$ of sulfur is introduced into the feedstock. The inhibiting effect of sulfur for Pt-catalyst is $77 \%$ in this case, which is equal to an isomerization reaction rate constant 3.0 times lower than the NiWS-catalyst.

The catalytic behaviors of the prepared TMS- and Pt-based bifunctional catalysts are quite similar in nitrogen-containing feedstock processing. Isomerization activity is inhibited by nitrogen through a similar mechanism, which differs from the one for Pt-catalysts poisoned by sulfur. The residual catalytic activity is the result of the strong limitation of the isomerization reaction, caused by nitrogen in the feedstock. The isomerization reaction rate constants evaluated during the processing of the feedstock with $50 \mathrm{ppm}$ of nitrogen increase from 0.09 to $0.21 \times 10^{4} \mathrm{~mol} \mathrm{~g}^{-1} \mathrm{~h}^{-1} \mu \mathrm{mol} / \mathrm{g}$ in the following order: Pt-, CoMoS-, NiWS-catalysts. In addition, nitrogen in the feedstock has a more intense inhibiting effect on isomerization catalytic activity. Reaching the steady state of n-hexadecane conversion takes about $20 \mathrm{~h}$ in the case of nitrogen poisoning, and about $38 \mathrm{~h}$ for sulfur-containing feedstock. 
Therefore, it can be concluded that transition metal-based bifunctional catalysts have a significant advantage over Pt-catalyst in n-alkanes isomerization, when the amount of sulfur in the feedstock is equal to, or higher than, $100 \mathrm{ppm}$. Nitrogen has an intensive inhibiting effect on both TMS- and Pt-containing bifunctional catalysts, which is most probably due to support acid sites poisoning, in which case, additional improvements of the support are required.

Supplementary Materials: The following are available online at http://www.mdpi.com/2073-4344/10/6/594/s1. Figure S1. XRD spectra of synthesized $\mathrm{Al}_{2} \mathrm{O}_{3}-\mathrm{SAPO}-11$ composite support; Figure S2. SEM image of $\mathrm{Al}_{2} \mathrm{O}_{3}-\mathrm{SAPO}-11$ composite support; Figure S3. Chromatogram of the feedstock $n-C_{16}$ in hexane.

Author Contributions: Conceptualization, A.P. (Aleksey Pimerzin), A.P. (Andrey Pimerzin); methodology, A.M., A.S., A.V.; software, A.V., A.P. (Andrey Pimerzin); validation, A.P. (Aleksey Pimerzin), A.G.; formal analysis, A.S., A.M.; investigation, A.S., A.P. (Aleksey Pimerzin), A.P. (Andrey Pimerzin); resources, V.V., A.G.; data curation, A.P. (Aleksey Pimerzin), A.S.; writing—original draft preparation, A.S., A.M.; writing-review and editing, A.V., A.P. (Aleksey Pimerzin); visualization, A.V., A.S.; supervision, A.P. (Aleksey Pimerzin), A.G.; project administration, A.P. (Aleksey Pimerzin); funding acquisition A.P. (Aleksey Pimerzin), A.G. All authors have read and agreed to the published version of the manuscript.

Funding: This research was financially supported by the Russian Science Foundation (Project No. 19-79-00293).

Conflicts of Interest: The authors declare no conflict of interest.

\section{References}

1. Mäki-Arvela, P.; Kaka khel, T.; Azkaar, M.; Engblom, S.; Murzin, D. Catalytic Hydroisomerization of Long-Chain Hydrocarbons for the Production of Fuels. Catalysts 2018, 8, 534. [CrossRef]

2. Len, C.; Luisi, R. Catalytic Methods in Flow Chemistry. Catalysts 2019, 9, 663. [CrossRef]

3. Lázaro, N.; Franco, A.; Ouyang, W.; Balu, A.; Romero, A.; Luque, R.; Pineda, A. Continuous-Flow Hydrogenation of Methyl Levulinate Promoted by Zr-Based Mesoporous Materials. Catalysts 2019, 9, 142. [CrossRef]

4. An, K.; Zhang, Q.; Alayoglu, S.; Musselwhite, N.; Shin, J.-Y.; Somorjai, G.A. High-Temperature Catalytic Reforming of $\mathrm{n}$-Hexane over Supported and Core-Shell Pt Nanoparticle Catalysts: Role of Oxide-Metal Interface and Thermal Stability. Nano Lett. 2014, 14, 4907-4912. [CrossRef] [PubMed]

5. Beltramini, J.; Trimm, D.L. Catalytic reforming of n-heptane on platinum, tin and platinum-tin supported on alumina. Appl. Catal. 1987, 31, 113-118. [CrossRef]

6. Weyda, H.; Köhler, E. Modern refining concepts—An update on naphtha-isomerization to modern gasoline manufacture. Catal. Today 2003, 81, 51-55. [CrossRef]

7. Akhmedov, V.M.; Al-Khowaiter, S.H. Recent Advances and Future Aspects in the Selective Isomerization of High n-Alkanes. Catal. Rev. 2007, 49, 33-139. [CrossRef]

8. Guisnet, M.; Gilson, J.-P. Zeolites for Cleaner Technologies Catalytic Science Series; Hutchings, G.J., Ed.; Imperial College Press: London, UK, 2002; Volume 3, ISBN 1-86094-329-2.

9. Martens, J.A.; Verboekend, D.; Thomas, K.; Vanbutsele, G.; Gilson, J.-P.; Pérez-Ramírez, J. Hydroisomerization of Emerging Renewable Hydrocarbons using Hierarchical Pt/H-ZSM-22 Catalyst. ChemSusChem 2013, 6, 421-425. [CrossRef]

10. Mortier, R.M.; Fox, M.F.; Malcolm, F.; Orszulik, S.T. Chemistry and Technology of Lubricants; Springer: Berlin/Heidelberg, Germany, 2010; ISBN 9781402086625.

11. Klein, A.; Keisers, K.; Palkovits, R. Formation of 1,3-butadiene from ethanol in a two-step process using modified zeolite- $\beta$ catalysts. Appl. Catal. A Gen. 2016, 514, 192-202. [CrossRef]

12. Mendes, P.S.F.; Mota, F.M.; Silva, J.M.; Ribeiro, M.F.; Daudin, A.; Bouchy, C. A systematic study on mixtures of Pt/zeolite as hydroisomerization catalysts. Catal. Sci. Technol. 2017, 7, 1095-1107. [CrossRef]

13. Guisnet, M. "Ideal” bifunctional catalysis over Pt-acid zeolites. Catal. Today 2013, 218-219, 123-134. [CrossRef]

14. Alvarez, F.; Ribeiro, F.R.; Perot, G.; Thomazeau, C.; Guisnet, M. Hydroisomerization and Hydrocracking of Alkanes: 7. Influence of the Balance between Acid and Hydrogenating Functions on the Transformation ofn-Decane on PtHY Catalysts. J. Catal. 1996, 162, 179-189. [CrossRef] 
15. Glotov, A.P.; Artemova, M.I.; Demikhova, N.R.; Smirnova, E.M.; Ivanov, E.V.; Gushchin, P.A.; Egazar'yants, S.V.; Vinokurov, V.A. A Study of Platinum Catalysts Based on Ordered Al-MCM-41 Aluminosilicate and Natural Halloysite Nanotubes in Xylene Isomerization. Pet. Chem. 2019, 59, 1226-1234. [CrossRef]

16. Radlik, M.; Śrębowata, A.; Juszczyk, W.; Matus, K.; Małolepszy, A.; Karpiński, Z. n-Hexane conversion on $\gamma$-alumina supported palladium-platinum catalysts. Adsorption 2019, 25, 843-853. [CrossRef]

17. van de Runstraat, A.; Kamp, J.A.; Stobbelaar, P.J.; van Grondelle, J.; Krijnen, S.; van Santen, R.A. Kinetics of Hydro-isomerization ofn-Hexane over Platinum Containing Zeolites. J. Catal. 1997, 171, 77-84. [CrossRef]

18. Suárez París, R.; L'Abbate, M.E.; Liotta, L.F.; Montes, V.; Barrientos, J.; Regali, F.; Aho, A.; Boutonnet, M.; Järås, S. Hydroconversion of paraffinic wax over platinum and palladium catalysts supported on silica-alumina. Catal. Today 2016, 275, 141-148. [CrossRef]

19. De Lucas, A.; Sánchez, P.; Fúnez, A.; Ramos, M.J.; Valverde, J.L. Influence of clay binder on the liquid phase hydroisomerization of n-octane over palladium-containing zeolite catalysts. J. Mol. Catal. A Chem. 2006, 259, 259-266. [CrossRef]

20. Wang, Y.; Tao, Z.; Wu, B.; Xu, J.; Huo, C.; Li, K.; Chen, H.; Yang, Y.; Li, Y. Effect of metal precursors on the performance of Pt/ZSM-22 catalysts for $\mathrm{n}$-hexadecane hydroisomerization. J. Catal. 2015, 322, 1-13. [CrossRef]

21. Zhu, S.; Liu, S.; Zhang, H.; Lü, E.; Ren, J. Investigation of synthesis and hydroisomerization performance of SAPO-11/Beta composite molecular sieve. Chin. J. Catal. 2014, 35, 1676-1686. [CrossRef]

22. Karakhanov, E.A.; Glotov, A.P.; Nikiforova, A.G.; Vutolkina, A.V.; Ivanov, A.O.; Kardashev, S.V.; Maksimov, A.L.; Lysenko, S.V. Catalytic cracking additives based on mesoporous MCM-41 for sulfur removal. Fuel Process. Technol. 2016, 153, 50-57. [CrossRef]

23. Karakhanov, E.; Maximov, A.; Zolotukhina, A.; Vinokurov, V.; Ivanov, E.; Glotov, A. Manganese and Cobalt Doped Hierarchical Mesoporous Halloysite-Based Catalysts for Selective Oxidation of p-Xylene to Terephthalic Acid. Catalysts 2019, 10, 7. [CrossRef]

24. Glotov, A.; Stytsenko, V.; Artemova, M.; Kotelev, M.; Ivanov, E.; Gushchin, P.; Vinokurov, V. Hydroconversion of Aromatic Hydrocarbons over Bimetallic Catalysts. Catalysts 2019, 9, 384. [CrossRef]

25. Kramer, G.M.; Schriesheim, A. Heptane Isomerization Mechanism. J. Phys. Chem. 1961, 65, $1283-1286$. [CrossRef]

26. Weitkamp, J. Hydrocracking, Cracking and Isomerization of Hydrocarbons.|Hydrocracken, cracken und isomerisieren von kohlenwasserstoffen. Erdoel Kohle-Erdgas-Petrochem 1978, 31, 13-22.

27. Krummenacher, J. Catalytic partial oxidation of higher hydrocarbons at millisecond contact times: Decane, hexadecane, and diesel fuel. J. Catal. 2003, 215, 332-343. [CrossRef]

28. Zhang, F.; Liu, Y.; Sun, Q.; Dai, Z.; Gies, H.; Wu, Q.; Pan, S.; Bian, C.; Tian, Z.; Meng, X.; et al. Design and preparation of efficient hydroisomerization catalysts by the formation of stable SAPO-11 molecular sieve nanosheets with 10-20 nm thickness and partially blocked acidic sites. Chem. Commun. 2017, 53, 4942-4945. [CrossRef]

29. Guo, L.; Fan, Y.; Bao, X.; Shi, G.; Liu, H. Two-stage surfactant-assisted crystallization for enhancing SAPO-11 acidity to improve n-octane di-branched isomerization. J. Catal. 2013, 301, 162-173. [CrossRef]

30. Deldari, H. Suitable catalysts for hydroisomerization of long-chain normal paraffins. Appl. Catal. A Gen. 2005, 293, 1-10. [CrossRef]

31. Bouchy, C.; Hastoy, G.; Guillon, E.; Martens, J.A. Fischer-Tropsch Waxes Upgrading via Hydrocracking and Selective Hydroisomerization. Oil Gas Sci. Technol. Rev. l'IFP 2009, 64, 91-112. [CrossRef]

32. Lakhapatri, S.L.; Abraham, M.A. Deactivation due to sulfur poisoning and carbon deposition on Rh-Ni/Al2O3 catalyst during steam reforming of sulfur-doped n-hexadecane. Appl. Catal. A Gen. 2009, 364, 113-121. [CrossRef]

33. Galperin, L.B. Hydroisomerization of N-decane in the presence of sulfur and nitrogen compounds. Appl. Catal. A Gen. 2001, 209, 257-268. [CrossRef]

34. Parmar, S.; Pant, K.K.; John, M.; Kumar, K.; Pai, S.M.; Newalkar, B.L. Hydroisomerization of n-hexadecane over Pt/ZSM-22 framework: Effect of divalent cation exchange. J. Mol. Catal. A Chem. 2015, 404-405, 47-56. [CrossRef] 
35. Höchtl, M.; Jentys, A.; Vinek, H. Hydroisomerization of Heptane Isomers over Pd/SAPO Molecular Sieves: Influence of the Acid and Metal Site Concentration and the Transport Properties on the Activity and Selectivity. J. Catal. 2000, 190, 419-432. [CrossRef]

36. Geng, C.-H.; Zhang, F.; Gao, Z.-X.; Zhao, L.-F.; Zhou, J.-L. Hydroisomerization of n-tetradecane over Pt/SAPO-11 catalyst. Catal. Today 2004, 93-95, 485-491. [CrossRef]

37. Martens, J.A.; Verboekend, D.; Thomas, K.; Vanbutsele, G.; Pérez-Ramírez, J.; Gilson, J.-P. Hydroisomerization and hydrocracking of linear and multibranched long model alkanes on hierarchical Pt/ZSM-22 zeolite. Catal. Today 2013, 218-219, 135-142. [CrossRef]

38. Corma, A.; Martínez, A.; Martínez-Soria, V. Hydrogenation of Aromatics in Diesel Fuels on Pt/MCM-41 Catalysts. J. Catal. 1997, 169, 480-489. [CrossRef]

39. Yasuda, H.; Yoshimura, Y. Hydrogenation of tetralin over zeolite-supported Pd-Pt catalysts in the presence of dibenzothiophene. Catal. Lett. 1997, 46, 43-48. [CrossRef]

40. Escobar, J.; Núñez, S.; Montesinos-Castellanos, A.; de los Reyes, J.A.; Rodríguez, Y.; González, O.A. Dibenzothiophene hydrodesulfurization over $\mathrm{PdPt} / \mathrm{Al}_{2} \mathrm{O}_{3}-\mathrm{TiO}_{2}$. Influence of Ti-addition on hydrogenating properties. Mater. Chem. Phys. 2016, 171, 185-194. [CrossRef]

41. Xiong, J.; Ma, Y. Catalytic Hydrodechlorination of Chlorophenols in a Continuous Flow Pd/CNT-Ni Foam Micro Reactor Using Formic Acid as a Hydrogen Source. Catalysts 2019, 9, 77. [CrossRef]

42. Flego, C.; Galasso, L.; Vidotto, S.; Faraci, G. Effects of $\mathrm{H}_{2} \mathrm{~S}$ on Bifunctional Catalysts; Elsevier: Amsterdam, The Netherlands, 1997; pp. 479-486.

43. Marafi, M.; Stanislaus, A.; Furimsky, E. Catalyst Deactivation. In Handbook of Spent Hydroprocessing Catalysts; Elsevier: Amsterdam, The Netherlands, 2017; pp. 67-140.

44. Topsøe, H.; Clausen, B.S.; Massoth, F.E. Hydrotreating Catalysis; Springer: Berlin/Heidelberg, Germany, 1996.

45. Xing, G.; Liu, S.; Guan, Q.; Li, W. Investigation on hydroisomerization and hydrocracking of C 15 -C $18 \mathrm{n}$ -alkanes utilizing a hollow tubular Ni-Mo/SAPO-11 catalyst with high selectivity of jet fuel. Catal. Today 2019, 330, 109-116.

46. Liu, P.; Wu, M.-Y.; Wang, J.; Zhang, W.-H.; Li, Y.-X. Hydroisomerization of n-heptane over MoP/H $\beta$ catalyst doped with metal additive. Fuel Process. Technol. 2015, 131, 311-316. [CrossRef]

47. Karakoulia, S.A.; Heracleous, E.; Lappas, A.A. Mild hydroisomerization of heavy naphtha on mono- and bi-metallic Pt and Ni catalysts supported on Beta zeolite. Catal. Today 2019. [CrossRef]

48. Stanislaus, A.; Marafi, A.; Rana, M.S. Recent advances in the science and technology of ultra low sulfur diesel (ULSD) production. Catal. Today 2010, 153, 1-68. [CrossRef]

49. van Veen, J.A.R. What's new? On the development of sulphidic HT catalysts before the molecular aspects. Catal. Today 2017, 292, 2-25. [CrossRef]

50. Vutolkina, A.V.; Makhmutov, D.F.; Zanina, A.V.; Maximov, A.L.; Glotov, A.P.; Sinikova, N.A.; Karakhanov, E.A. Hydrogenation of Aromatic Substrates over Dispersed Ni-Mo Sulfide Catalysts in System $\mathrm{H}_{2} \mathrm{O} /$ CO. Pet. Chem. 2018, 58, 528-534. [CrossRef]

51. Vutolkina, A.V.; Makhmutov, D.F.; Zanina, A.V.; Maximov, A.L.; Kopitsin, D.S.; Glotov, A.P.; Egazar'yants, S.V.; Karakhanov, E.A. Hydroconversion of Thiophene Derivatives over Dispersed Ni-Mo Sulfide Catalysts. Pet. Chem. 2018, 58, 1227-1232. [CrossRef]

52. Han, W.; Nie, H.; Long, X.; Li, M.; Yang, Q.; Li, D. Effects of the support BrØnsted acidity on the hydrodesulfurization and hydrodenitrogention activity of sulfided NiMo/Al2O3catalysts. Catal. Today 2017, 292, 58-66.

53. Yu, Q.; Zhang, L.; Guo, R.; Sun, J.; Fu, W.; Tang, T.; Tang, T. Catalytic performance of CoMo catalysts supported on mesoporous ZSM-5 zeolite-alumina composites in the hydrodesulfurization of 4,6-dimethyldibenzothiophene. Fuel Process. Technol. 2017, 159, 76-87. [CrossRef]

54. Wang, X.; Mei, J.; Zhao, Z.; Zheng, P.; Chen, Z.; Gao, D.; Fu, J.; Fan, J.; Duan, A.; Xu, C. Self-Assembly of Hierarchically Porous ZSM-5/SBA-16 with Different Morphologies and Its High Isomerization Performance for Hydrodesulfurization of Dibenzothiophene and 4,6-Dimethyldibenzothiophene. ACS Catal. 2018, 8 , 1891-1902. [CrossRef]

55. Mériaudeau, P.; Tuan, V.A.; Sapaly, G.; Nghiem, V.T.; Naccache, C. Pore size and crystal size effects on the selective hydroisomerisation of C8 paraffins over Pt-Pd/SAPO-11, Pt-Pd/SAPO-41 bifunctional catalysts. Catal. Today 1999, 49, 285-292. [CrossRef] 
56. Yadav, R.; Sakthivel, A. Silicoaluminophosphate molecular sieves as potential catalysts for hydroisomerization of alkanes and alkenes. Appl. Catal. A Gen. 2014, 481, 143-160. [CrossRef]

57. Lee, E.; Yun, S.; Park, Y.-K.; Jeong, S.-Y.; Han, J.; Jeon, J.-K. Selective hydroisomerization of n-dodecane over platinum supported on SAPO-11. J. Ind. Eng. Chem. 2014, 20, 775-780. [CrossRef]

58. Kim, M.Y.; Lee, K.; Choi, M. Cooperative effects of secondary mesoporosity and acid site location in Pt/SAPO-11 on n-dodecane hydroisomerization selectivity. J. Catal. 2014, 319, 232-238. [CrossRef]

59. Pimerzin, A.A.; Roganov, A.A.; Verevkin, S.P.; Konnova, M.E.; Pilshchikov, V.A.; Pimerzin, A.A. Bifunctional catalysts with noble metals on composite Al2O3-SAPO-11 carrier and their comparison with CoMoS one in n-hexadecane hydroisomerization. Catal. Today 2019, 329, 71-81. [CrossRef]

60. Topsøe, H.; Clausen, B.S.; Topsøe, N.-Y.; Zeuthen, P. Progress in the Design of Hydrotreating Catalysts Based on Fundamental Molecular Insight. In Studies in Surface Science and Catalysis; Elsevier: Amsterdam, The Netherlands, 1989; Volume 53, pp. 77-102. ISBN 9780444882110.

61. Topsøe, H. The role of Co-Mo-S type structures in hydrotreating catalysts. Appl. Catal. A Gen. 2007, 322, 3-8. [CrossRef]

62. Pimerzin, A.A.; Savinov, A.A.; Ishutenko, D.I.; Verevkin, S.P.; Pimerzin, A.A. Isomerization of Linear Paraffin Hydrocarbons in the Presence of Sulfide CoMo and NiW Catalysts on $\mathrm{Al}_{2} \mathrm{O}_{3}$-SAPO- 11 Support. Russ. J. Appl. Chem. 2019, 92, 1772-1779. [CrossRef]

63. Mériaudeau, P.; Tuan, V.A.; Nghiem, V.T.; Lai, S.Y.; Hung, L.N.; Naccache, C. SAPO-11, SAPO-31, and SAPO-41 Molecular Sieves: Synthesis, Characterization, and Catalytic Properties in n-Octane Hydroisomerization. J. Catal. 1997, 169, 55-66. [CrossRef]

64. Kasztelan, S.; Toulhoat, H.; Grimblot, J.; Bonnelle, J.P. A geometrical model of the active phase of hydrotreating catalysts. Appl. Catal. 1984, 13, 127-159. [CrossRef]

65. Hensen, E.J.; Kooyman, P.; van der Meer, Y.; van der Kraan, A.; de Beer, V.H.; van Veen, J.A.; van Santen, R. The Relation between Morphology and Hydrotreating Activity for Supported MoS2 Particles. J. Catal. 2001, 199, 224-235. [CrossRef]

66. Pimerzin, A.A.; Nikulshin, P.A.; Mozhaev, A.V.; Pimerzin, A.A.; Lyashenko, A.I. Investigation of spillover effect in hydrotreating catalysts based on $\mathrm{Co}_{2} \mathrm{Mo}_{1} 0$-heteropolyanion and cobalt sulphide species. Appl. Catal. B Environ. 2015, 168-169, 396-407. [CrossRef] 